\title{
Organic amendment effects on nematode distribution within aggregate fractions in agricultural soils
}

\author{
Xiaoke Zhang ${ }^{1, *}, X^{*}{ }^{1}{ }^{1}$, Shixiu Zhang ${ }^{2}$, Yuehua $\mathrm{Xing}^{3}$, Wenju Liang ${ }^{1}$ \\ 1 State Key Laboratory of Forest and Soil Ecology, Institute of Applied Ecology, Chinese Academy of Sciences, Shenyang 110164, China \\ 2 Northeast Institute of Geography and Agroecology, Chinese Academy of Sciences, Changchun 130012, China \\ 3 Environmental Resources and Agricultural Energy Research Institute, Liaoning Academy of Agricultural Sciences, Shenyang 110161, China
}

\section{ARTICLE INFO}

\section{Article history:}

Received June 19, 2018

Revised October 22, 2018

Accepted November 10, 2018

\section{Keywords:}

Organic amendment

Soil aggregate fractions

Nematode communities

Macroaggregate

Microaggregate

\begin{abstract}
A B S T R A C T
To evaluate the effect of organic amendments on soil nematode community composition and diversity within aggregate fractions, a study was initiated in agricultural soils with four-year organic amendments. Soil samples were collected from the plow layer $(0-20 \mathrm{~cm})$ under three cornfield management scenarios: 1) conventional cropping (CK, corn straw removal and no organic manure application); 2) straw retention (SR, incorporation of chopped corn stalk); and 3) manure application (MA, chicken manure input). The soil samples were fractionated into four aggregate sizes, i.e., >2 mm (large macroaggregates), 1-2 mm (macroaggregates), 0.25-1 $\mathrm{mm}$ (small macroaggregates), and $<0.25 \mathrm{~mm}$ (microaggregates, silt and clay fractions). The composition and diversity of soil nematode communities were determined within each aggregate fraction. The results showed that both SR and MA treatments significantly increased the percentage of macroaggregates $(>1 \mathrm{~mm})$ and only MA treatment strongly increased the mean weight diameter compared to the $\mathrm{CK}(P<0.05)$. The abundance of total nematodes and four trophic groups were affected significantly by the aggregate fractions and their higher abundance occurred in the larger aggregates. The effects of aggregate size on most nematode genera were significant. Bacterivores in the small macroaggregates and microaggregates, and fungivores in the large macroaggregates were significantly different among treatments. The percentage of bacterivores increased after the application of organic materials, while that of fungivores decreased. It can be concluded that organic management significantly affects soil aggregation and soil characteristics within aggregates, and the aggregate size subsequently influences the distribution of nematode communities.
\end{abstract}

(c) Higher Education Press 2019

\section{Introduction}

Organic amendments have been recognized as a sustainable agricultural strategy to improve soil fertility and modify both soil aggregation and soil biotic community composition (Jiang et al., 2013; Zhang et al., 2016a; Hlava et al., 2017). Organic

\footnotetext{
* Corresponding author

E-mail address: zxk@iae.ac.cn (X. Zhang)
}

matter addition provide carbon substrate as cementing agent to involve in soil aggregation process and then enhance soil aggregate stability (Ahmad et al., 2008; Sarker et al., 2018). Soil organic amendment is also crucial for soil fauna due to the increase of nutrient availability and interaction between soil fauna and nutrient (Biederman et al., 2008).

Soil nematodes play essential roles in functioning of soil ecosystems (Wang et al., 2018). They live in water-filled pore spaces with different sizes and shapes, which largely depend on the size and arrangement of soil aggregates (Lebron et al., 
2002). Therefore, the distribution of soil nematodes within different aggregates was likely driven by food distribution, living space and other factors induced by organic amendment (Briar et al., 2011a). Many studies showed that soil nematode community composition and diversity was affected by organic amendment practices such as the residue coverage of vetch, oat, cotton-gin and rye, and the application of swine manure, dairy cow or beef calf manure (Nahar et al., 2006; Hlava et al., 2017). However, the effects of organic amendment on the distribution of soil nematodes within different soil aggregate fractions are still not sufficiently understood. To understand the biological effect of organic amendment in agricultural soils, soil biotic communities should be explored at different spatial scales. Distribution of nematode communities within aggregates will provide a holistic measure of the biotic and functional status of soils (Briar et al., 2007; Hlava et al., 2017).

Some studies have concerned biological effect in soil aggregates, such as microbial patterns, i.e. inside and outside of soil aggregates, as influenced by agricultural management (Mummey et al., 2006; Briar et al., 2011a; Zhang et al., 2013a). Nielsen et al. (2010) found that spatial isolation at microscales within soil aggregates may have a stronger influence on the species richness of microorganisms than the smallscale heterogeneity. Due to the close interrelationships between nematodes and microbe, the addition of organic materials to soil can increase the microbial activity and then enlarge the food base for microbial grazers such as free-living nematodes (Briar et al., 2011b; Jiang et al., 2017). Briar et al. (2011a) found that nematode communities were more limited by habitable pore space for the soil fractions than by resource availability compared to microbial communities. Furthermore, the changes induced by organic input in soil nematode communities within aggregates may have important implications for the stability of soil food web. Most studies have primarily focused on the relationship between the distribution of soil microbes and soil aggregate fractions (Nielsen et al., 2010; Li et al., 2018; Liang et al., 2019). Relatively little is known about the effect of organic amendments on the distribution of nematodes within soil aggregates. It is important to assess nematode community composition in microhabitats for comprehensive insight into the structure and function of soil food web.

Therefore, our objectives were to investigate the effects of organic amendments on the distribution of soil nematode communities within different aggregate fractions. We hypothesize that the effects of organic amendment on soil nematode communities vary at the level of soil aggregates, and macroaggregates benefit the multiplication of nematodes due to the increase of nutrient and space.

\section{Materials and methods}

\subsection{Experimental site}

This experiment was set up in April 2007 at a soil amendment site $\left(42^{\circ} 27^{\prime} \mathrm{N}, 122^{\circ} 28^{\prime} \mathrm{E}\right)$, which was located in Zhangwu county of Liaoning province, China, where corn (Zea mays L.) was the main crop. This region lies in the northern temperature zone and is characterized by a continental monsoon climate, with a mean annual temperature of $7.1^{\circ} \mathrm{C}$, mean annual precipitation of $510 \mathrm{~mm}$ and mean annual evaporation of $1832 \mathrm{~mm}$. The maximum average wind speed is $25 \mathrm{~m} \cdot \mathrm{s}^{-1}$ in April. The soil is classified as Cambisol (IUSS working group WRB, 2014) with $1.23 \%$ soil organic matter, $840 \mathrm{mg} \cdot \mathrm{kg}^{-1}$ total $\mathrm{N}, 77.00 \mathrm{mg} \cdot \mathrm{kg}^{-1}$ available $\mathrm{N}$ (exchangeable ammonium- $\mathrm{N}$ and nitrate- $\mathrm{N}), 4.10 \mathrm{mg} \cdot \mathrm{kg}^{-1}$ available $\mathrm{P}$, $78.00 \mathrm{mg} \cdot \mathrm{kg}^{-1}$ available $\mathrm{K}, \mathrm{pH}\left(\mathrm{H}_{2} \mathrm{O}\right) 8.20$ at $0-20 \mathrm{~cm}$ depth in 2007 (Liang et al., 2011). Before the experiment, corn was planted in the field for more than 20 years. The agricultural activities consisted of rotary tillage followed by sowing corn in the spring, and inter-tillage and artificial weeding in the jointing stage of corn. No herbicide was applied during the experimental process.

\subsection{Experimental design}

The experimental design was a randomized complete block of nine plots (three treatments with three replicates, $30 \mathrm{~m}^{2}$ each). The plots were separated from each other by a 1-m-wide alley. The three treatments included a conventional cropping system (CK, corn straw removal and no application of organic manure), a straw retention system (SR, application of $9000 \mathrm{~kg} \cdot \mathrm{ha}^{-1}$ chopped corn stalks) and a manure application system (MA, inputs of $15000 \mathrm{~kg} \cdot \mathrm{ha}^{-1}$ chicken manure) (Liang et al., 2011; Zhang et al., 2014). The above-mentioned application rates were in accordance with routine practices in the study site. The corn stover was chopped to about $3-5 \mathrm{~cm}$ and applied on the surface after harvest. And manure was applied before sowing together with other chemical fertilizers as base fertilizers. For each treatment, the application rates of $\mathrm{N}$ (urea), $\mathrm{P}_{2} \mathrm{O}_{5}$ (diammonium phosphate), and $\mathrm{K}_{2} \mathrm{O}$ (potassium chloride) were the same, which were 210,60 , and $60 \mathrm{~kg} \cdot \mathrm{ha}^{-1}$, respectively. Chemical fertilizer and organic amendments were applied during each growing season from 2007 to 2011 (Liang et al., 2011).

\subsection{Soil sampling}

Before corn sowing, soil samples were collected from the plow layer $(0-20 \mathrm{~cm})$ of the nine plots (three treatments with three replicates) in April 2011. In the central rows of each plot, two pits were dug. After removing the surface residue, one undisturbed soil block $(10 \mathrm{~cm}$ length $\times 10 \mathrm{~cm}$ width $\times$ $20 \mathrm{~cm}$ height) was taken from each pit. The soil samples from two pits of each plot were homogenized roughly and sorted out as one replicate, and then stored at $4^{\circ} \mathrm{C}$ and used for the separation of aggregates.

\subsection{Aggregate-size separation}

Dry-sieving of soil may reduce the disruption of physical habitat of soil microbial communities (Schutter and Dick, 2002). Thus, the dry-sieving method was considered to be 
better than wet-sieving for studying biological communities within the aggregates (Gartzia-Bengoetxea et al., 2009). Field-moist soils were dried at $4{ }^{\circ} \mathrm{C}$ until the gravimetric water content decreased to approximately $80 \mathrm{~g} \cdot \mathrm{kg}^{-1}$ soil. At this moisture level, soils could be passed through finer sieves for aggregate-size separation (Zhang et al., 2014). One part was used to determine soil nematodes of bulk soil, and the other part continued to be sieved. After the removal of visible plant residues and stones, the soil samples were passed through a $5 \mathrm{~mm}$ sieve (Schutter and Dick, 2002).

For each time, soil aggregates were separated by placing $100 \mathrm{~g}$ of cool-dried sub-samples ( $<5 \mathrm{~mm}$ ) into a nest of sieves mounted on a Retsch AS200 Control (Retsch Technology, Düsseldorf, Germany) and mechanically shaken (amplitude $1.5 \mathrm{~mm}$ ) for $2 \mathrm{~min}$ to divide the soils into the following four aggregate-size classes: $>2 \mathrm{~mm}$ (large macroaggregates), 1-2 mm (macroaggregates), 0.25-1 mm (small macroaggregates) and $<0.25 \mathrm{~mm}$ (microaggregates and silt and clay fractions) (Gartzia-Bengoetxea et al., 2009; Briar et al., 2011a; Zhang et al., 2012a). Small aggregates passing through a $0.25 \mathrm{~mm}$ sieve are considered too small for nematode to enter and this fraction will thus referred to as inter-aggregate soil and space (Briar et al., 2011a). The sieving was conducted several times until the amount of the smallest faction was greater than $50 \mathrm{~g}$. Then fractionated samples for each aggregate-size class from each sieving were combined to make composite samples to determine mean weight diameter and composition of nematode communities. Mean weight diameter, MWD $=\Sigma$ (percentage of sample weight on sieve $\times$ the mean diameter of the size classes), was calculated as an index for characterizing the structure of the bulk soil (Van Bavel, 1950).

\subsection{Soil nematode identification}

Nematodes were extracted with a modified cotton-wool filter from a $50 \mathrm{~g}$ soil sample from each aggregate-size class after dry-sieving or from bulk soil without sieving (Verschoor and De Goede, 2000). Nematode populations were expressed as the number of nematodes per $100 \mathrm{~g}$ of dry soil. Using an inverted compound microscope $(100 \times$ magnification $)$, at least 100 nematodes from each sample were identified to the genus level. If the population was less than 100 individuals, all individuals were identified. The trophic groups of soil nematodes were assigned according to their feeding habits and life-history characteristics (Yeates et al., 1993). Most genera belonging to Tylenchidae and Nordiidae were assigned to plant parasites and omnivores-predators, respectively, except for Filenchus and Longidorella, which were classified as fungivores and plant parasites, respectively, as supported by recent evidence (Okada et al., 2005; Erum and Shahina, 2010).

\subsection{Nematode community analyses}

The following ecological indices for soil nematodes were calculated: Trophic diversity, TD $=1 / \Sigma p_{i}^{2}$; Simpson's dom- inance index, $\lambda=\sum p_{i}^{2}$; Shannon diversity, $\mathrm{H}^{\prime}=-\sum p_{i} \ln p_{i}$, where $p_{i}$ is the percentage of individuals in the ith taxon; Maturity index, $\mathrm{Ml}=\Sigma v(i) \cdot f(i)$, where $v(i)$ is the $c-p$ value of taxon $i, f(i)$ is the frequency of taxon $i$ in a sample (Bongers and Ferris, 1999; Zhang et al., 2013b); Nematode channel ratio, $\mathrm{NCR}=B /(B+F)$, where $B$ and $F$ are the percentages of the nematode fauna allocated to bacterivorous and fungivorous groups (Yeates, 2003); Enrichment index, EI = $100 \times$ $\mathrm{e} /(\mathrm{b}+\mathrm{e})$; Structure index, $\mathrm{SI}=100 \times \mathrm{s} /(\mathrm{b}+\mathrm{s})$; Basal index, $\mathrm{BI}=100 \times \mathrm{b} /(\mathrm{b}+\mathrm{e}+\mathrm{s})$ and channel index, $\mathrm{Cl}=100 \times$ $\left(0.8 \mathrm{Fu}_{2} /\left(3.2 \mathrm{Ba}_{1}+0.8 \mathrm{Fu}_{2}\right)\right.$ (Ferris et al., 2001), where b, e and $\mathrm{S}$ is the abundance of individuals in guilds in the basal component, enrichment component and structural component weighted by their $k_{b}, k_{e}$ and $k_{s}$ values, respectively. $k_{b}$ is the weighting assigned to guilds $\mathrm{Ba}_{2}$ and $\mathrm{Fu}_{2}, \mathrm{k}_{\mathrm{e}}$ to guilds $\mathrm{Ba}_{1}$ and $\mathrm{Fu}_{2}$, and $\mathrm{k}_{\mathrm{s}}$ to guilds $\mathrm{Ba}_{3}-\mathrm{Ba}_{5}, \mathrm{Fu}_{3}-\mathrm{Fu}_{5}, \mathrm{Op}_{3}-\mathrm{Op}_{5}$. $\mathrm{Ba}_{x}, \mathrm{Fu}_{x}, \mathrm{Op}_{x}, \mathrm{Pp}_{x}$ (where $x=1-5$ ) represent the functional guilds of nematodes that are bacterivores $(\mathrm{Ba})$, fungivores $(\mathrm{Fu})$, omnivores-predators $(\mathrm{Op})$ or plant parasites $(\mathrm{Pp})$ where the guilds have the character indicated by $x$ on the colonizer-persister (cp) scale (1-5) according to their $r$ and $K$ characteristics and nematodes in the same functional guilds respond similarly to food web enrichment and to environmental perturbation.

\subsection{Statistical analysis}

Nematode abundances were $\ln (x+1)$ transformed to normalize data prior to statistical analysis. All statistical analyses were run with SPSS statistical software (SPSS Inc., Chicago, IL). To test the main effects and interactions of organic treatment and aggregate effects, general linear model analysis of variance designed for split plot was performed with organic treatment and aggregate class as fixed factors and replicates as random factors. Treatment was considered the main factor and aggregate-size class a sub-plot factor. One-way ANOVA was used to analyze the treatment effect on each aggregate fraction and the aggregate-size effect on each treatment. Comparisons of the means for aggregate fraction and management systems were made using Tukey's honestly significant difference. Differences at $P<0.05$ were considered statistically significant.

\section{Results}

\subsection{Aggregate-size distribution and mean weight diameter}

For each treatment, aggregate-size percentage varied significantly with aggregate-size classes (Table 1). Small macroaggregates $(0.25-1 \mathrm{~mm})$ dominated and their percentages were higher than those of other aggregate sizes. Compared with the $\mathrm{CK}$, both SR and MA treatments significantly increased the percentage of macroaggregates (>2 $\mathrm{mm}$ and $1-2 \mathrm{~mm})(P<0.01)$, and only MA treatment significantly increased the values of mean weight diameter (MWD) $(P<0.05)$. 
Table 1 Aggregate-size distribution and mean weight diameter under different treatments.

\begin{tabular}{lccccc}
\hline Treatment & \multicolumn{3}{c}{ Aggregate proportion in size class (\%) } & \multicolumn{1}{c}{ MWD } \\
\cline { 2 - 5 } & $<0.25 \mathrm{~mm}$ & $0.25-1 \mathrm{~mm}$ & $1-2 \mathrm{~mm}$ & 19.47 & 1.17 \\
CK & 26.60 & 40.12 & 13.80 & 22.66 & 1.31 \\
SR & 23.91 & 36.42 & 17.01 & 24.47 & 1.39 \\
MA & 20.01 & 37.19 & 18.32 & & \\
\hline
\end{tabular}

$\mathrm{CK}$, conventional cropping system; SR, incorporation of chopped corn straw; MA, inputs of chicken manure; MWD, mean weight diameter.

3.2 Total nematode abundance and trophic groups within aggregates

The effect of organic treatments on the total nematode abundance was not significant and the aggregate effect was significant $(P<0.01)$. The average values of total nematode abundance (100 g $\mathrm{g}^{-1}$ dry soil) across agricultural treatments were significantly higher in macroaggregates (>2 and $1-2$ $\mathrm{mm}$ ) and lower in microaggregates compared with bulk soil $(P<0.05)$ (Fig. 1). For each treatment, the total nematode abundance increased significantly with increasing aggregate size $(P<0.05)$ (Fig. 1). Total nematode abundance was negatively correlated with the percentage of aggregates $(r=$ $0.40, P<0.05)$.

The aggregate effects on the abundances of four trophic groups $(P<0.01)$ and the treatment effects on those of bacterivores and fungivores $(P<0.05)$ were significant (Fig. 1). The highest abundances of the four trophic groups all appeared in the large macroaggregates or macroaggregates, and the lowest in the microaggregates (Fig. 1). Bacterivores and fungivores made up $64 \%-88 \%$ of the total nematode abundance. Bacterivores in the small macroaggregates and microaggregates, and fungivores in the large macroaggregates were significantly different among treatments $(P<0.05)$, with highest values occurring in the MA or SR treatments. In the bulk soil, no significant treatment effects on four trophic groups were observed.

\subsection{Nematode community composition}

Forty-two genera belonging to 20-one families were identified (Table 2). The effects of aggregate size on all genera, except for Paraphelenchus and Rotylenchus, were significant $(P<0.05)$ (Data not shown in Table 2). The effects of organic treatments on 13 genera, such as Cephalobus, Plectus and Tylencholaimus, were significant $(P<0.01)$. Some rare genera, such as Aporcelaimellus, Longidorella, Macroposthonia, Panagrolaimus and Thornia were found in only one or a few sample(s), and generally showed no significant responses to organic amendments.

\subsection{Nematode ecological indices}

With increasing aggregate size, the values of TD, $\mathrm{H}^{\prime}$ and $\mathrm{MI}$ increased significantly, and $\lambda$ and $\mathrm{BI}$ decreased significantly $(P<0.01)$ (Table 3$)$. The values of TD, $\mathrm{H}^{\prime}, \mathrm{Ml}$ and $\mathrm{Cl}$ significantly decreased in the MA treatment compared with

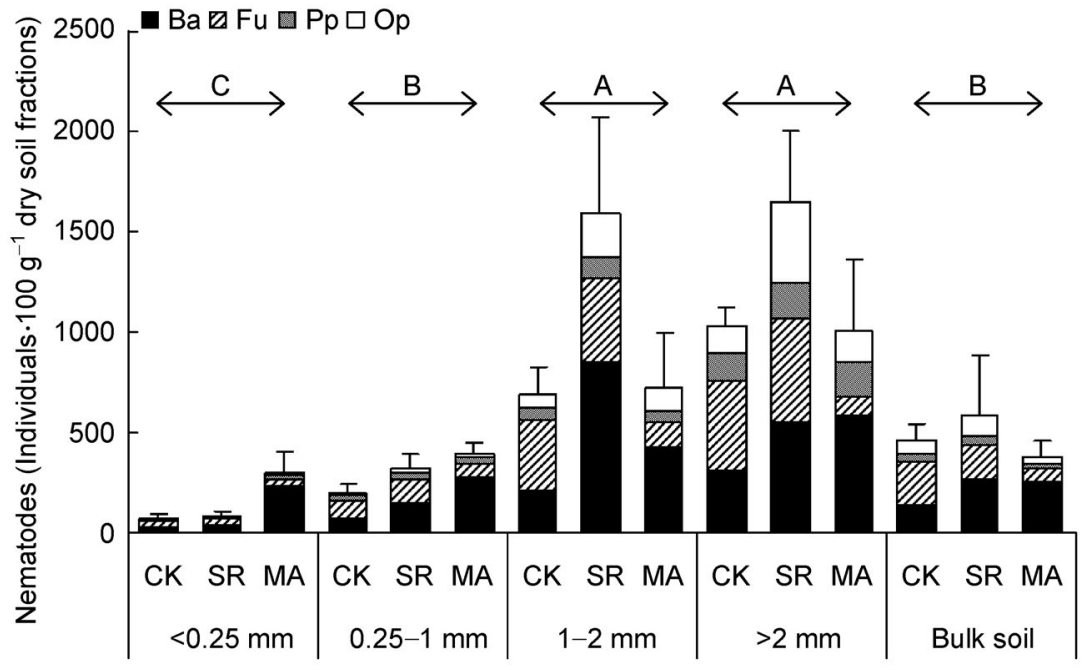

Fig. 1 Total nematode abundance (individuals $\cdot 100 \mathrm{~g}^{-1}$ dry soil) within four soil aggregate fractions under different treatments. Error-bars represent the standard error. Grouped means designated by inclusion line with different capital letters indicated significant differences among aggregate fractions determined using Tukey's HSD $(P<0.05)$. CK, conventional cropping system; SR, incorporation of chopped corn straw; $\mathrm{MA}$, inputs of chicken manure. Ba, bacterivores; Fu, fungivores; $\mathrm{Pp}$, plant-parasites; Op, omnivores-predators. 
Table 2 Percentage contribution (\%) of various nematode genera to the nematode assemblage within aggregates.

\begin{tabular}{|c|c|c|c|c|c|c|c|c|c|c|c|c|c|c|}
\hline \multirow[t]{2}{*}{$\overline{\mathrm{TG}}$} & \multirow{2}{*}{$\begin{array}{l}\text { Nematode } \\
\text { family }\end{array}$} & \multirow{2}{*}{$\begin{array}{l}\text { Treatment } \\
\text { Aggregate }(\mathrm{mm})\end{array}$} & \multicolumn{4}{|c|}{ CK } & \multicolumn{4}{|c|}{ SR } & \multicolumn{4}{|c|}{ MA } \\
\hline & & & $<0.25$ & $0.25-1$ & $1-2$ & $>2$ & $<0.25$ & $0.25-1$ & $1-2$ & $>2$ & $<0.25$ & $.25-1$ & $1-2$ & $>2$ \\
\hline \multirow[t]{14}{*}{$\overline{\mathrm{Ba}}$} & \multirow[t]{8}{*}{ Cephalobidae } & Acrobeles & 9.7 & 2.6 & 1.2 & 3.1 & 0.0 & 3.8 & 2.0 & 1.9 & 1.3 & 1.6 & 1.6 & 2.9 \\
\hline & & Acrobeloides & 0.0 & 0.0 & 0.9 & 1.8 & 6.3 & 0.0 & 1.6 & 3.3 & 1.7 & 0.3 & 4.5 & 4.8 \\
\hline & & Acrobelophis & 1.5 & 1.7 & 0.6 & 0.0 & 2.3 & 2.9 & 3.3 & 0.0 & 4.4 & 4.5 & 5.4 & 0.0 \\
\hline & & Cephalobus & 8.5 & 7.8 & 4.7 & 4.1 & 9.8 & 9.7 & 11.3 & 6.9 & 16.1 & 26.0 & 23.1 & 18.7 \\
\hline & & Cervidellus & 1.5 & 5.0 & 4.6 & 3.1 & 2.7 & 1.0 & 1.3 & 0.3 & 2.2 & 10.4 & 1.9 & 0.3 \\
\hline & & Chiloplacus & 1.6 & 0.0 & 0.0 & 0.3 & 0.0 & 0.0 & 0.3 & 0.0 & 1.3 & 0.0 & 0.3 & 0.3 \\
\hline & & Eucephalobus & 5.2 & 0.9 & 0.9 & 2.6 & 1.1 & 1.7 & 0.6 & 4.7 & 0.0 & 0.6 & 1.0 & 2.3 \\
\hline & & Heterocephalobus & 1.9 & 0.9 & 0.6 & 0.0 & 2.1 & 1.0 & 2.3 & 2.2 & 5.3 & 2.2 & 1.6 & 0.0 \\
\hline & Alaimidae & Alaimus & 0.0 & 2.8 & 3.4 & 6.8 & 0.0 & 6.5 & 10.0 & 8.4 & 0.3 & 1.3 & 3.8 & 15.6 \\
\hline & \multirow[t]{3}{*}{ Plectidae } & Plectus & 0.0 & 9.2 & 7.1 & 4.5 & 2.3 & 13.1 & 14.2 & 0.3 & 0.0 & 0.0 & 0.6 & 0.0 \\
\hline & & Wilsonema & 0.0 & 0.0 & 0.0 & 0.0 & 0.0 & 0.3 & 0.3 & 0.0 & 0.0 & 0.0 & & \\
\hline & & Panagrolaimus & 0.0 & 0.0 & 0.0 & 0.5 & 0.0 & 0.0 & 0.0 & 0.0 & 0.0 & 0.0 & 0.0 & 0.0 \\
\hline & Prismatolaimidae & Prismatolaimus & 1.5 & 3.3 & 2.5 & 0.8 & 0.0 & 0.3 & 1.0 & 0.0 & 0.0 & 0.7 & 0.6 & 0.0 \\
\hline & Rhabditidae & Rhabditis & 7.9 & 5.5 & 2.5 & 1.0 & 17.8 & 7.7 & 3.2 & 2.8 & 34.9 & 23.3 & 14.3 & 12.8 \\
\hline \multirow[t]{10}{*}{$\mathrm{Fu}$} & \multirow[t]{2}{*}{ Aphelenchoididae } & Aphelenchoides & 5.0 & 7.6 & 7.4 & 3.9 & 1.0 & 2.9 & 1.3 & 0.6 & 0.0 & 1.0 & 0.0 & 0.0 \\
\hline & & Rhadinaphelenchus & 0.0 & 0.4 & 0.0 & 0.0 & 0.0 & 0.0 & 0.0 & 0.0 & 0.0 & 0.0 & 0.0 & 0.0 \\
\hline & \multirow[t]{2}{*}{ Aphelenchidae } & Aphelenchus & 4.8 & 6.9 & 8.2 & 4.2 & 10.5 & 2.6 & 5.8 & 2.4 & 3.3 & 2.6 & 1.0 & 2.4 \\
\hline & & Paraphelenchus & 3.5 & 3.9 & 2.7 & 7.1 & 15.2 & 12.0 & 4.2 & 8.6 & 6.3 & 6.1 & 5.9 & 2.6 \\
\hline & Diphtherophoridae & Diphtherophora & 0.0 & 1.4 & 1.6 & 3.2 & 0.0 & 1.3 & 5.1 & 6.4 & 0.3 & 0.0 & 0.0 & 1.5 \\
\hline & Anguinidae & Ditylenchus & 1.3 & 2.4 & 2.4 & 2.2 & 3.4 & 4.2 & 3.9 & 0.6 & 1.5 & 2.3 & 0.6 & 1.0 \\
\hline & Tylenchidae & Filenchus & 7.1 & 3.3 & 6.4 & 2.4 & 7.6 & 8.7 & 6.2 & 3.7 & 0.9 & 2.6 & 2.2 & 0.0 \\
\hline & \multirow[t]{3}{*}{ Leptonchidae } & leptonchus & 8.2 & 0.0 & 4.5 & 0.0 & 0.0 & 0.0 & 0.0 & 0.0 & 0.0 & 0.0 & 0.0 & 0.0 \\
\hline & & Dorylaimoides & 0.0 & 0.0 & 0.0 & 0.0 & 0.0 & 0.0 & 0.0 & 0.3 & 0.0 & 0.0 & 0.0 & 0.0 \\
\hline & & Tylencholaimus & 6.3 & 15.5 & 19.2 & 21.6 & 0.6 & 3.6 & 2.3 & 10.1 & 1.3 & 2.3 & 6.7 & 2.9 \\
\hline \multirow[t]{10}{*}{$\mathrm{Pp}$} & \multirow[t]{2}{*}{ Tylenchidae } & Boleodorus & 0.0 & 0.0 & 0.0 & 0.0 & 0.0 & 0.0 & 0.0 & 0.0 & 0.6 & 0.0 & 0.0 & 0.0 \\
\hline & & Malenchus & 1.5 & 5.3 & 2.7 & 10.1 & 0.6 & 0.6 & 1.6 & 0.6 & 0.0 & 0.0 & 3.5 & 3.1 \\
\hline & Dolichodoridae & Dolichorhynchus & 0.0 & 0.0 & 0.0 & 0.9 & 0.0 & 0.0 & 0.0 & 0.0 & 0.0 & 0.0 & 0.0 & 0.0 \\
\hline & Belondiridae & Dorylaimellus & 0.0 & 0.0 & 0.0 & 0.0 & 0.0 & 0.0 & 0.0 & 3.2 & 0.0 & 0.0 & 0.6 & 5.2 \\
\hline & \multirow[t]{2}{*}{ Hoplolaimidae } & Helicotylenchus & 3.2 & 1.0 & 0.9 & 0.8 & 1.6 & 3.3 & 2.3 & 5.1 & 3.0 & 1.6 & 0.6 & 1.0 \\
\hline & & Rotylenchus & 14.6 & 6.3 & 4.9 & 0.9 & 6.7 & 0.6 & 1.6 & 3.1 & 13.4 & 5.0 & 4.8 & 5.5 \\
\hline & Nordiidae & Longidorella & 0.0 & 0.0 & 0.0 & 0.3 & 0.0 & 0.6 & 0.0 & 0.0 & 0.0 & 0.0 & 0.0 & 0.0 \\
\hline & Criconematidae & Macroposthonia & 1.6 & 0.3 & 0.0 & 0.0 & 0.0 & 0.0 & 0.0 & 0.0 & 0.0 & 0.3 & 0.0 & 0.0 \\
\hline & Pratylenchidae & Pratylenchoides & 3.0 & 0.4 & 0.3 & 0.0 & 5.1 & 4.5 & 1.9 & 0.6 & 0.9 & 1.6 & 0.0 & 1.2 \\
\hline & & Tylenchorhynchus & 0.0 & 0.0 & 0.0 & 0.0 & 0.0 & 0.0 & 0.0 & 0.3 & 0.0 & 0.0 & 0.0 & 0.0 \\
\hline \multirow[t]{8}{*}{ Op } & Aporcelaimidae & Aporcelaimellus & 0.0 & 0.0 & 0.0 & 0.0 & 0.0 & 0.7 & 0.0 & 0.0 & 0.0 & 0.0 & 0.0 & 0.0 \\
\hline & \multirow[t]{2}{*}{ Discolaimidae } & Discolaimium & 0.0 & 0.5 & 0.6 & 0.8 & 0.0 & 0.3 & 0.7 & 3.8 & 0.0 & 0.0 & 0.0 & 0.6 \\
\hline & & Discolaimus & 0.0 & 0.0 & 0.6 & 0.0 & 0.0 & 0.6 & 0.0 & 0.0 & 0.0 & 0.0 & 1.3 & 0.0 \\
\hline & \multirow[t]{3}{*}{ Qudsianematidae } & Dorydorella & 0.0 & 0.0 & 0.9 & 2.4 & 1.1 & 2.3 & 0.0 & 1.9 & 0.6 & 0.0 & 7.1 & 0.3 \\
\hline & & Microdorylaimus & 0.0 & 0.0 & 0.6 & 2.6 & 0.0 & 1.6 & 4.2 & 3.2 & 0.0 & 0.3 & 1.0 & 0.3 \\
\hline & & Thonus & 0.0 & 4.4 & 6.8 & 5.7 & 0.0 & 0.6 & 7.5 & 14.1 & 0.3 & 2.5 & 6.0 & 14.6 \\
\hline & Longidoridae & Longidorus & 0.0 & 0.3 & 0.3 & 1.3 & 0.0 & 0.0 & 0.0 & 0.3 & 0.0 & 0.0 & 0.0 & 0.0 \\
\hline & Nordiidae & Thornia & 0.6 & 0.3 & 0.0 & 1.0 & 2.1 & 1.0 & 0.0 & 0.0 & 0.0 & 0.9 & 0.0 & 0.0 \\
\hline
\end{tabular}

TG, trophic group; CK, conventional cropping system; SR, incorporation of chopped corn straw; MA, inputs of chicken manure. Ba, bacterivores; Fu, fungivores; Pp, plant-parasites; Op, omnivores-predators. 
the CK and SR treatments regardless of aggregate sizes $(P<0.05)$. The values of $\lambda, N C R$ and BI were also significantly different among treatments regardless of aggregate sizes $(P<0.05)$.

The SI was significantly affected by the organic treatment and the aggregate size $(P<0.01)$, while the El was not. The soil nematode faunal analysis (Fig. 2) showed a shift that plots from quadrat $C$ at the large macroaggregates and macroaggregates to quadrat $A$ and $D$ at the microaggregates, which indicated that the less disturbed or relative undisturbed stable environment in $>1 \mathrm{~mm}$ macroaggregates compared to other fractions. This shift was more obvious in the organic amendment treatments (SR and MA) than the CK.

\section{Discussion}

4.1 Effect of organic amendments on soil nematode communities

The effect of organic amendments on the trophic group within the aggregate fractions was significant. Organic amendments affected the densities of opportunistic bacterivores and fungivores not only by increasing the supply of nutrient resources, but also by changing soil habitat (Biederman et al., 2008; Wang et al., 2018). For example, the corn stalk application increase soil carbon and nitrogen, soil moisture and soil temperature, which are all important factors being related to soil nematode communities (Thakur et al., 2014; Zhang et al., 2016a; Sun et al., 2018). Additionally, organic amendment with a high level of available nutrient source influenced microbial community structure, activities and functions, and then soil nematode communities, especially for bacterivores and fungivores, were affected through predator-prey interactions (Zhang et al., 2016b; Cesarano et al., 2017; Zheng and Marschner, 2017). Bacteria and fungi have distinct metabolic abilities to break down substrates with different qualities. Bacteria prefers to easily-available and fungi prefers to refractory substrates (Fabian et al., 2017), which explain a different response to organic treatments between bacterivores and fungivores in our study. Bacterivores as the opportunists of nematodes were more sensitive to higher nutrient resources (García-Álvarez et al., 2004). Significant increases in the NCR also supported that organic matter decomposition was achieved primarily through the bacterial-based energy pathway, which was faster than the fungal-based channel (Ruess and Ferris, 2004; Ferris and Bongers, 2006). This opposite trend between bacterivores and fungivores was also the reason for no significant organic amendment effect on the total nematode abundance. Nahar et al. (2006) and Jiang et al. (2013) also proved that there were high numbers of bacterivores and low diversity indices in

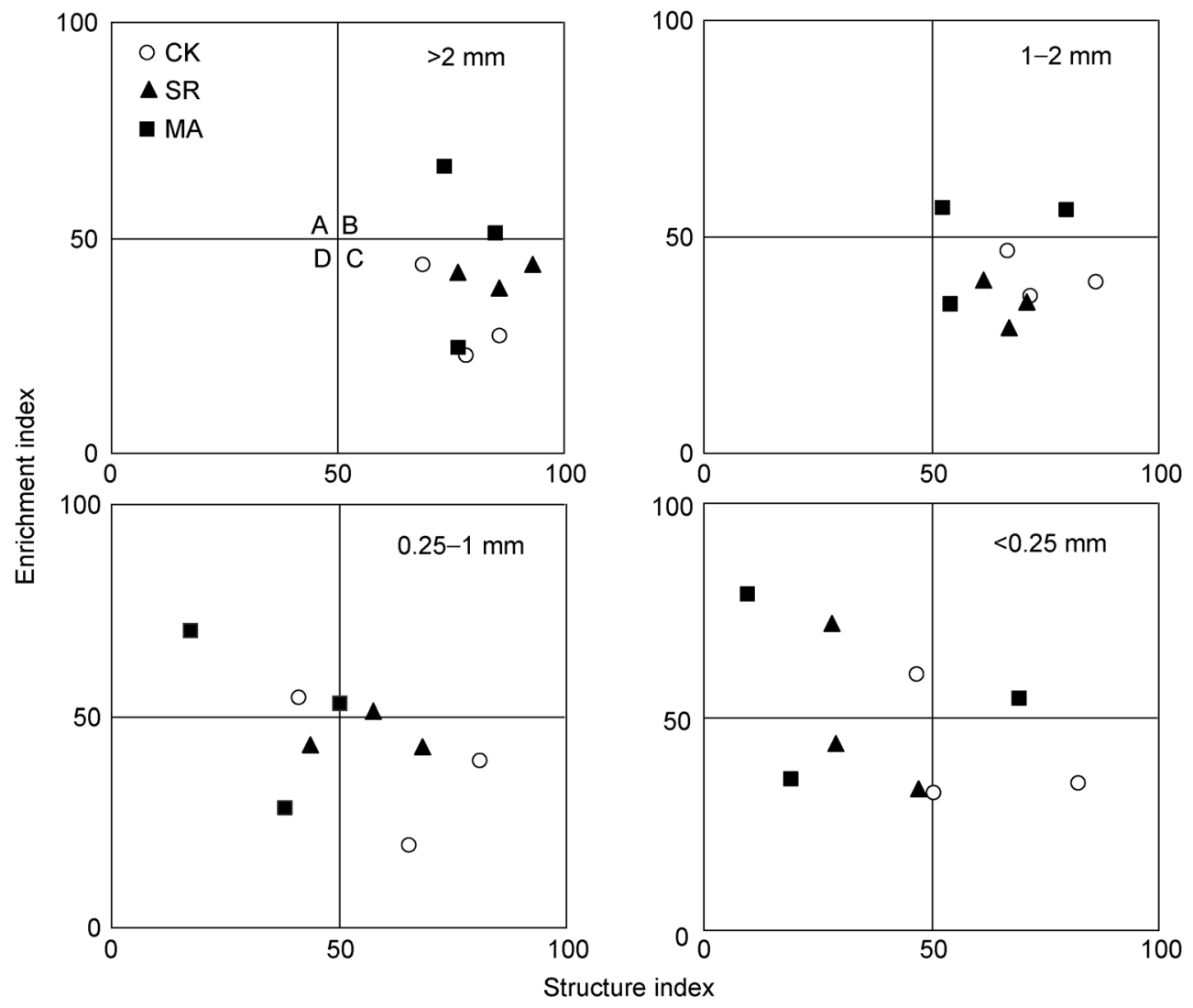

Fig. 2 Nematode faunal analysis within four soil aggregate fractions under different organic treatments. CK, conventional cropping system; $\mathrm{SR}$, incorporation of chopped corn straw; MA, inputs of chicken manure. 
manure-amended plots. However, Griffiths et al. (2010) considered that the bacterial:fungal ratio or decomposition pathway measured from bacterivores and fungivores gave conflicting results in many respects. Measuring multiple indicators so as not to rely on a single attribute was needed to identify the mechanisms responsible for the organic improvement.

\subsection{Effect of aggregate fractions on soil nematode communities}

Although the small macroaggregate was the dominant class, higher nematode abundances were observed in the macroaggregates (>2 $\mathrm{mm}$ and 1-2 $\mathrm{mm}$ fractions). The change of total nematode abundance increased with increasing aggregate size but not percentage of the aggregate fractions. Being consistent with the total nematode abundance, a significant increase in the four trophic groups was found as aggregate size increased. Not only the abundance but also the diversity of soil nematodes increased significantly by increasing aggregate size, as indicated by the TD and H'. Nematode faunal analysis showing by SI and El indicated that habitats in macroaggregates provided free-living nematodes with a relatively stable living environment relative to small aggregates. A relatively higher abundance of omnivores-predators resulted in a lower $\mathrm{Bl}$ in the large macroaggregates. Probably the small space of aggregates fractions might be one of the important limiting factors for nematodes such as the omnivores-predators with relatively large body. Briar et al. (2011a) considered that nematode distribution depended largely on not only their body size, but also their feeding habits and the availability of nutrient materials within aggregate fractions. The macroaggregates provided more intra-aggregate pore space for nematodes survival and more nutrients than microaggregates (Briar et al., 2011a). Additionally, the rarity of roots, small pore size and low pore volume, and physical constraints within and between the microaggregates were also the causes of nematode sparseness (Bonkowski et al., 2009).

\subsection{Effect of organic amendments on soil aggregate fractions}

Organic amendments significantly increased the percentage of macroaggregates $(>1 \mathrm{~mm})$ and mean weight diameter (MWD). Celik et al. (2010) and Jiang et al. (2017) found that applications of organic materials significantly increased the values of MWD and promoted the formation of macroaggregates. Kushwaha et al. (2001) showed that in a tropical dryland agroecosystem of Varanasi in India, residue retention increased the percentage of soil in the $>4.75 \mathrm{~mm}$ water-stable soil aggregate fraction. Organic residue could be a catalyst for biological activity and induce binding of soil particles onto macroaggregates (Zhang et al., 2013a). Organic amendment measures, such as crop residue or manure application, enhanced soil aggregate stability through the positive effects on soil binding agents (Zhang et al., 2014). Therefore, organic amendment is an available strategy for increasing aggrega- tion and reducing soil degradation (Ahmad et al., 2008).

4.4 The relationships among organic amendments, soil aggregate fractions and nematode communities

The organic amendment provided organic resources and aggregate binding agents to soil, which can bind small macroaggregates or microaggregates into large macroaggregates, then strengthened aggregate stability (Zhang et al., 2012a). The effect of organic amendments on soil nematodes resulted primarily from the change of nutrient resources (Zhao et al., 2013; Zhang et al., 2014), whereas the influence of aggregate fractions on soil nematodes mainly resulted from the soil physical structure change (Briar et al., 2011a). Since organic amendments affected the distribution of aggregates, and aggregation influenced the availability of organic material inputs, it is difficult to separate their concurrent effect on soil nematode communities. For example, many of the studied nematode genera were sensitive to both the aggregate size and organic amendment treatment. The alteration of soil nematode genera might be due to a concurrent effect of soil microclimate change and bottom-up control produced by organic amendments and aggregate size (Zhao et al., 2014). The effects of the two types of organic amendments were different. Straw retention increased the total nematode abundance and diversity in larger aggregates and was an important driver of soil nematode communities (Okada and Harada, 2007; Zhang et al., 2012b). The manure treatment tended to decrease the total abundance and diversity of nematodes compared with the control. This may depend on that the manure treatment increased the intensity and frequency of extreme disturbances of the soil ecosystem, thus negatively affecting nematode communities. MI was negatively related to disturbance and their low values in MA treatment also proved that more disturbance from manure application.

Probably the small size of soil nematodes (typically $40 \mu \mathrm{m}$ to $1.0 \mathrm{~mm}$ in length) made them unable to reshape soil, which forced them to use existing pore paces, water cavities, or channels for locomotion within soil (Neher, 2010). The effect of soil nematodes on aggregates may be indirect through regulating soil nutrient cycling and availability and then contribute to the development of improved soil structure (Biederman et al., 2008). Therefore, the effect of aggregate fractions on soil nematodes was greater than that of soil nematodes on aggregate fractions.

Physical and resources constraints of soil habitats were the main factors responsible for the distribution of nematodes within soil aggregates: (1) the porosphere (inter-aggregate pores) and aggregatusphere (intra-aggregate pores) are important microhabitats for soil nematodes; large aggregates have more intra-aggregate pore space with immobile water where soil fauna preferred to reside and prey on microbes (Jiang et al., 2013; Wang et al., 2018), but the small aggregate increased the inter-aggregate pores with mobile water. (2) Another possible explanation of more nematodes living in macroaggregates than microaggregates was resource con- 
Table 3 Effect of treatments and aggregate sizes on nematode ecological indices.

\begin{tabular}{|c|c|c|c|c|c|c|}
\hline Indices & Treat & $<0.25 \mathrm{~mm}$ & $0.25-1 \mathrm{~mm}$ & $1-2 \mathrm{~mm}$ & $>2 \mathrm{~mm}$ & \\
\hline \multirow[t]{4}{*}{ TD } & CK & $2.44 \pm 0.25$ & $2.62 \pm 0.08$ & $2.53 \pm 0.33$ & $2.93 \pm 0.07$ & $A$ \\
\hline & SR & $2.51 \pm 0.32$ & $2.65 \pm 0.13$ & $2.62 \pm 0.30$ & $3.38 \pm 0.13$ & $A$ \\
\hline & MA & $1.82 \pm 0.41$ & $1.85 \pm 0.24$ & $2.50 \pm 0.44$ & $2.52 \pm 0.02$ & B \\
\hline & & B & B & $A B$ & $A$ & \\
\hline \multirow[t]{4}{*}{$\lambda$} & CK & $0.13 \pm 0.01$ & $0.10 \pm 0.01$ & $0.11 \pm 0.03$ & $0.12 \pm 0.04$ & $A B$ \\
\hline & SR & $0.20 \pm 0.05$ & $0.08 \pm 0.01$ & $0.09 \pm 0.01$ & $0.09 \pm 0.01$ & $B$ \\
\hline & MA & $0.38 \pm 0.18$ & $0.21 \pm 0.05$ & $0.13 \pm 0.02$ & $0.14 \pm 0.01$ & A \\
\hline & & $A$ & $B$ & $B$ & B & \\
\hline \multirow[t]{4}{*}{$\mathrm{H}^{\prime}$} & CK & $2.20 \pm 0.02$ & $2.61 \pm 0.02$ & $2.63 \pm 0.13$ & $2.57 \pm 0.19$ & $A$ \\
\hline & SR & $1.98 \pm 0.22$ & $2.70 \pm 0.06$ & $2.72 \pm 0.04$ & $2.66 \pm 0.04$ & A \\
\hline & MA & $1.61 \pm 0.48$ & $2.12 \pm 0.22$ & $2.41 \pm 0.15$ & $2.27 \pm 0.06$ & $B$ \\
\hline & & B & A & $A$ & A & \\
\hline \multirow[t]{4}{*}{ MI } & CK & $2.25 \pm 0.39$ & $2.56 \pm 0.27$ & $2.85 \pm 0.20$ & $3.03 \pm 0.21$ & $A$ \\
\hline & SR & $1.88 \pm 0.23$ & $2.33 \pm 0.13$ & $2.57 \pm 0.06$ & $3.07 \pm 0.18$ & $A$ \\
\hline & MA & $1.68 \pm 0.29$ & $1.91 \pm 0.23$ & $2.45 \pm 0.19$ & $2.70 \pm 0.15$ & $B$ \\
\hline & & $B$ & $B$ & $A$ & A & \\
\hline \multirow[t]{4}{*}{ NCR } & CK & $0.55 \pm 0.16$ & $0.48 \pm 0.11$ & $0.36 \pm 0.11$ & $0.38 \pm 0.10$ & C \\
\hline & SR & $0.54 \pm 0.12$ & $0.57 \pm 0.06$ & $0.64 \pm 0.08$ & $0.48 \pm 0.09$ & B \\
\hline & MA & $0.83 \pm 0.09$ & $0.81 \pm 0.07$ & $0.78 \pm 0.06$ & $0.85 \pm 0.01$ & $A$ \\
\hline & & $A$ & A & $A$ & A & \\
\hline \multirow[t]{4}{*}{$\mathrm{BI}$} & CK & $28.45 \pm 6.90$ & $27.56 \pm 5.59$ & $20.60 \pm 4.14$ & $19.40 \pm 3.42$ & $B$ \\
\hline & SR & $37.48 \pm 6.26$ & $31.44 \pm 4.14$ & $28.25 \pm 1.70$ & $13.32 \pm 3.83$ & $A B$ \\
\hline & MA & $33.20 \pm 11.46$ & $36.79 \pm 6.61$ & $27.33 \pm 6.09$ & $17.22 \pm 2.43$ & $A$ \\
\hline & & $A$ & A & $A B$ & B & \\
\hline \multirow[t]{4}{*}{$\mathrm{Cl}$} & CK & $56.71 \pm 22.11$ & $70.43 \pm 17.67$ & $77.08 \pm 11.46$ & $72.55 \pm 7.03$ & A \\
\hline & SR & $63.11 \pm 27.50$ & $51.39 \pm 8.15$ & $66.38 \pm 13.27$ & $63.73 \pm 10.08$ & A \\
\hline & MA & $22.47 \pm 15.38$ & $31.21 \pm 22.52$ & $19.22 \pm 10.47$ & $17.26 \pm 8.22$ & $B$ \\
\hline & & $\mathrm{A}$ & $\mathrm{A}$ & $\mathrm{A}$ & A & \\
\hline
\end{tabular}

Capital letters in lines and rows indicate significant differences among aggregate fractions and organic treatments determined using Tukey's HSD, respectively $(P<0.05)$.

straints. The abundance of free-living nematodes was consistent with the presence of large amounts of bacteria (Jiang et al., 2017). The inter-aggregate pores is a transient niche, and nematodes preferentially migrate where the food resource is located. However, intra-aggregate pore can form aggregate enclosures, a narrow but possibly resource-rich search area, of which were more facilitative for nematodes survival and predation (Jiang et al., 2018).

\section{Conclusions}

Organic amendments increased the proportion of macroaggregates, mean weight diameter and stimulated the bacterivores. The effect of organic treatments appeared to be more evident on community composition than the total abundance of nematodes. The effects of organic amendment on soil nematode communities vary with the different soil aggregate fractions. More nematodes prefer to live in macroaggtegates. In conclusion, the soil physical structure, resource constraints and predator-prey interaction associated with organic amend- ments play important roles in the distribution of soil nematode communities within different aggregate fractions.

\section{Acknowledgments}

This research was supported by the National Key Research \& Development Plan of China (No. 2016YFD0300204).

\section{References}

Ahmad, R., Arshad, M., Khalid, A., Zahir, Z.A., 2008. Effectiveness of organic-/bio-fertilizer supplemented with chemical fertilizers for improving soil water retention, aggregate stability, growth and nutrient uptake of maize (Zea mays L.). Journal of Sustainable Agriculture 31, 57-77.

Biederman, L.A., Boutton, T.W., Whisenant, S.G., 2008. Nematode community development early in ecological restoration: The role of organic amendments. Soil Biology \& Biochemistry 40, 2366-2374.

Bongers, T., Ferris, H., 1999. Nematode community structure as a 
bioindicator in environmental monitoring. Trends in Ecology \& Evolution 14, 224-228.

Bonkowski, M., Villenave, C., Griffiths, B., 2009. Rhizosphere fauna: the functional and structural diversity of intimate interactions of soil fauna with plant roots. Plant and Soil 321, 213-233.

Briar, S.S., Fonte, S.J., Park, I., Six, J., Scow, K., Ferris, H., 2011a The distribution of nematodes and soil microbial communities across soil aggregate fractions and farm management systems. Soil Biology \& Biochemistry 43, 905-914.

Briar, S.S., Grewal, P.S., Somasekhar, N., Stinner, D., Miller, S.A., 2007. Soil nematode community, organic matter, microbial biomass and nitrogen dynamics in field plots transitioning from conventional to organic management. Applied Soil Ecology 37, 256-266

Briar, S.S., Miller, S.A., Stinner, D., Kleinhenz, M.D., Grewal, P.S., 2011b. Effects of organic transition strategies for peri-urban vegetable production on soil properties, nematode community, and tomato yield. Applied Soil Ecology 47, 84-91.

Celik, I., Gunal, H., Budak, M., Akpinar, C., 2010. Effects of long-term organic and mineral fertilizers on bulk density and penetration resistance in semi-arid Mediterranean soil conditions. Geoderma 160, 236-243.

Cesarano, G., Filippis, F.D., Storia, A.L., Scala, F., Bonanomi, G., 2017. Organic amendment type and application frequency affect crop yields, soil fertility and microbiome composition. Applied Soil Ecology 120, 254-264.

Erum, Y.I., Shahina, F., 2010. Taxonomic studies on parasitic and soil nematodes found associated with wheat in Pakistan. Pakistan Journal of Nematology 28, 1-58.

Fabian, J., Zlatanovic, S., Mutz, M., Premke, K., 2017. Fungalbacterial dynamics and their contribution to terrigenous carbon turnover in relation to organic matter quality. ISME Journal 11, 415 425.

Ferris, H., Bongers, T., 2006. Nematode indicators of organic enrichment. Journal of Nematology 38, 3-12.

Ferris, H., Bongers, T., de Goede, R.G.M., 2001. A framework for soil food web diagnostics: Extension of the nematode faunal analysis concept. Applied Soil Ecology 18, 13-29.

García-Álvarez, A., Arias, M., Díez-Rojo, M.A., Bello, A., 2004. Effect of agricultural management on soil nematode trophic structure in a Mediterranean cereal system. Applied Soil Ecology 27, 197-210.

Gartzia-Bengoetxea, N., González-Arias, A., Merino, A., Martínez de Arano, I., 2009. Soil organic matter in soil physical fractions in adjacent semi-natural and cultivated stands in temperate Atlantic forests. Soil Biology \& Biochemistry 41, 1674-1683.

Griffiths, B.S., Ball, B.C., Daniell, T.J., Hallett, P.D., Neilson, R., Wheatley, R.E., Osler, G., Bohanec, M., 2010. Integrating soil quality changes to arable agricultural systems following organic matter addition, or adoption of a ley-arable rotation. Applied Soil Ecology 46, 43-53.

Hlava, J., Száková, J., Vadlejch, J., Čadková, Z., Balík, J., Tlustoš, P., 2017. Long-term application of organic matter based fertilisers: Advantages or risks for soil biota? A review. Environmental Reviews 25, 408-414 doi:10.1139/er-2017-0011.

IUSS working group W.R.B., 2014. World reference base for soil resources 2014, International soil classification system for naming soils and creating legends for soil maps. World Soil Resources Reports No. 106, FAO, Rome.

Jiang, Y.J., Liu, M.Q., Zhang, J.B., Chen, Y., Chen, X.Y., Chen, L.J., Li, H.X., Zhang, X.X., Sun, B., 2017. Nematode grazing promotes bacterial community dynamics in soil at the aggregate level. ISME Journal 11, 2705-2717.

Jiang, Y.J., Qian, H.Y., Wang, X.Y., Chen, L.J., Liu, M.Q., Li, H.X., Sun, B., 2018. Nematodes and microbial community affect the sizes and turnover rates of organic carbon pools in soil aggregates Soil Biology and Biochemistry 119, 22-31.

Jiang, Y.J., Sun, B., Jin, C., Wang, F., 2013. Soil aggregate stratification of nematodes and microbial communities affects the metabolic quotient in an acid soil. Soil Biology \& Biochemistry 60 , 1-9.

Kushwaha, C.P., Tripathi, S.K., Singh, K.P., 2001. Soil organic matter and water-stable aggregates under different tillage and residue conditions in a tropical dryland agroecosystem. Applied Soil Ecology 16, 229-241.

Lebron, I., Suarez, D.L., Schaap, M.G., 2002. Soil pore size and geometry as a result of aggregate-size distribution and chemical composition. Soil Science 167, 165-172.

Li, F.Q., Xue, C., Quu, P.F., Liu, Y.X., Shi, J.X., Shen, B., Yang, X.M., Shen, Q.R., 2018. Soil aggregate size mediates the responses of microbial communities to crop rotation. European Journal of Soil Biology 88, 48-56.

Liang, A.Z., Zhang, Y., Zhang, X.P., Yang, X.M., McLaughlin, N., Chen, X.W., Guo, Y.F., Jia, S.X., Zhang, S.X., Wang, L.X., Tang, J.W., 2019. Investigations of relationships among aggregate pore structure, microbial biomass, and soil organic carbon in a Mollisol using combined nondestructive measurements and phospholipid fatty acid analysis. Soil \& Tillage Research 185, 94-101.

Liang, W.J., Wu, X., Zhang, S.X., Xing, Y.H., Wang, R., 2011. Effect of organic amendments on soil water storage in the aeolian sandy land of Northeast China. 2011 International Conference on Electrical and Control Engineering1538-1540.

Mummey, D., Holben, W., Six, J., Stahl, P., 2006. Spatial stratification of soil bacterial populations in aggregates of diverse soils. Microbial Ecology 51, 404-411.

Nahar, M.S., Grewal, P.S., Miller, S.A., Stinner, D., Stinner, B.R., Kleinhenz, M.D., Wszelaki, A., Doohan, D., 2006. Differential effects of raw and composted manure on nematode community, and its indicative value for soil microbial, physical and chemical properties. Applied Soil Ecology 34, 140-151.

Neher, D.A., 2010. Ecology of plant and free-living nematodes in natural and agricultural soil. Annual Review of Phytopathology 48, 371-394.

Nielsen, U.N., Osler, G.H.R., Campbell, C.D., Neilson, R., Burslem, D. F.R.P., van der Wal, R., 2010. The enigma of soil animal species diversity revisited: The role of small-scale heterogeneity. PLoS One 5, e11567.

Okada, H., Harada, H., 2007. Effects of tillage and fertilizer on nematode communities in a Japanese soybean field. Applied Soil Ecology 35, 582-598.

Okada, H., Harada, H., Kadota, I., 2005. Fungal feeding habits of six nematode isolates in the genus. Soil Biology \& Biochemistry 37 , $1113-1120$. 
Ruess, L., Ferris, H., 2004. Decomposition pathways and successional changes. Proceedings of the 4th International Congress of Nematology, In: Cook, R.C., Hunt, D.J. (Eds) Nematology Monographs and Perspectives, Brill, Leiden, Netherlands, 1-10.

Sarker, T.C., Incerti, G., Spaccini, R., Piccolo, A., Mazzoleni, S., Bonanomi, G., 2018. linking organic matter chemistry with soil aggregate stability: Insight from ${ }^{13} \mathrm{C}$ NMR spectroscopy. Soil Biology \& Biochemistry 117, 175-184.

Schutter, M.E., Dick, R.P., 2002. Microbial community profiles and activities among aggregates of winter 24 fallow and cover-cropped soil. Soil Science Society of America Journal 66, 142-153.

Sun, F., Pan, K.W., Li, Z.L., Wang, S.Z., Tariq, A., Olatunji, O.A., Sun, X.M., Zhang, L., Shi, W.Y., Wu, X.G., 2018. Soybean supplementation increases the resilience of microbial and nematode communities in soil to extreme rainfall in an agroforestry system. Science of the Total Environment 626, 776-784.

Thakur, M.P., Reich, P.B., Fisichelli, N.A., Stefanski, A., Cesarz, S., Dobies, T., Rich, R.L., Hobbie, S.E., Eisenhauer, N., 2014. Nematode community shifts in response to experimental warming and canopy conditions are associated with plant community changes in the temperate-boreal forest ecotone. Oecologia 175, 713-723.

Van Bavel, C.H.M., 1950. Mean weight-diameter of soil aggregates as a statistical index of aggregation. Soil Sci. Soc. Am. Proc. 14, 20 23.

Verschoor, B.C., De Goede, R.G.M., 2000. The nematode extraction efficiency of the Oostenbrink elutriator-cottonwool filter method with special reference to nematode body size and life strategy. Nematol. 2, 325-342.

Wang, S.Q., Li, T.X., Zhen, Z.C., 2018. Response of soil aggregateassociated microbial and nematode communities to tea plantation age. Catena 171, $475-484$.

Yeates, G.W., 2003. Nematodes as soil indicators: functional and biodiversity aspects. Biology and Fertility of Soils 37, 199-210.

Yeates, G.W., Bongers, T., de Goede, R.G.M., Freckman, D.W., Georgieva, S.S., 1993. Feeding habits in soil nematode families and genera - an outline for soil ecologists. Journal of Nematology 25, 315-331.
Zhang, S.X., Li, Q., Lv, Y., Zhang, X.P., Liang, W.J., 2013 a. Contributions of soil biota to $C$ sequestration varied with aggregate fractions under different tillage systems. Soil Biology \& Biochemistry $62,147-156$.

Zhang, S.X., Li, Q., Zhang, X.P., Wei, K., Chen, L.J., Liang, W.J., 2012a. Effects of conservation tillage on soil aggregation and aggregate binding agents in black soil of Northeast China. Soil \& Tillage Research 124, 196-202.

Zhang, X.K., Li, Q., Zhu, A.N., Liang, W.J., Zhang, J.B., Steinberger, Y., 2012b. Effects of tillage and residue management on soil nematode communities in North China. Ecological Indicators 13, 75-81.

Zhang, X.K., Liang, W.J., Li, Q., 2013b. Forest soil nematodes in Changbai Mountain-Morphology and distribution. Beijing, China Agricultural Press. pp. 1-174.

Zhang, X.K., Wu, X., Zhang, S.X., Xing, Y.H., Wang, R., Liang, W.J., 2014. Organic amendment effects on aggregate-associated organic $\mathrm{C}$, microbial biomass $\mathrm{C}$ and glomalin in agricultural soils. Catena 123, 188-194.

Zhang, Z.Y., Zhang, X.K., Mahamood, M., Zhang, S.Q., Huang, S.M., Liang, W.J., 2016a. Effect of long-term combined application of organic and inorganic fertilizers on soil nematode communities within aggregates. Scientific Reports 6, 31118.

Zhang, Z.Y., Zhang, X.K., Xu, M.G., Zhang, S.Q., Huang, S.M., Liang, W.J., 2016b. Responses of soil micro-food web to long-term fertilization in a wheat -maize rotation system. Applied Soil Ecology 98, 56-64.

Zhao, J., Shao, Y.H., Wang, X.L., Neher, D.A., Xu, G.L., Li, Z.A., Fu, S. L., 2013. Sentinel soil invertebrate taxa as bioindicators for forest management practices. Ecological Indicators 24, 236-239.

Zhao, J., Wan, S.Z., Zhang, C.L., Liu, Z.F., Zhou, L.X., Fu, S.L., 2014. Contributions of understory and/or overstory vegetations to soil microbial PLFA and nematode diversities in Eucalyptus monocultures. PLoS One 9, e85513.

Zheng, B., Marschner, P., 2017. Residue addition frequency influences respiration, microbial biomass and nutrient availability in soil amended with high and low $\mathrm{C} / \mathrm{N}$ residue. Journal of Soil Science and Plant Nutrition 17, 1-13. 